\title{
RESPON PRODUKSI RUMPUT BEDE (Brachiaria decumbens) AKIBAT PERLAKUAN HORMON DEKAMON PADA BERBAGAI FREKUENSI PENYEMPROTAN GANDASIL D
}

\author{
Diana Sawen, M. Aff'an Muin, dan Susilowati \\ Jurusan Peternakan, Fakultas Peternakan Universitas Papua \\ Jl. Gunung Salju Amban Manokwari Papua Barat 98314 \\ e-mail: sawendian@yahoo.com
}

\begin{abstract}
ABSTRAK
Penelitian bertujuan untuk mengetahui respon produksi rumput Brachiaria decumbens akibat perlakuan pemberian dekamon sebagai zat pengatur tumbuh pada berbagai frekuensi penyemprotan pupuk daun gandasil. Penelitian berlangsung selama 4,5 bulan, bertempat di Balai Pembibitan Ternak dan Hijauan Makanan Ternak (BPT-HMT) Dinas Peternakan dan Kesehatan Hewan Provinsi Papua Barat, Kampung Sumber Boga, Distrik Masni, Kabupaten Manokwari dan Laboratorium Nutrisi dan Makanan Ternak Fapet UNIPA Manokwari. Rancangan eksperimen yang digunakan adalah rancangan acak lengkap (RAL) dengan dua perlakuan. Perlakuan dekamon (D) dengan 6 taraf yaitu Do (tanpa pemberian), D1=0,4 ml/250 ml air, D2 = 0,5 ml/250 ml air, D3=0,6 ml/250 ml air, D4=0,7 ml/250 ml air dan D5=0,8 ml/250 ml air. Masingmasing taraf perlakuan diulang 5 kali. Selanjutnya menggunakan 3 petak percobaan dengan ukuran 2,4 $\times 2$ $\mathrm{m}^{2}$ /petak untuk perlakuan frekuensi penyemprotan pupuk daun dengan Gandasil D, masing-masing petak I (So) untuk tanpa penyemprotan, petak II (S1) untuk penyemprotan $1 \mathrm{kali} / \mathrm{minggu}$ dan petak III (S2) untuk penyemprotan $2 \mathrm{kali} /$ minggu. Data dianalisis secara statistik dengan analisis ragam dan perbedaan antara taraf perlakuan dianalisis dengan uji t. Hasil penelitian menunjukkan bahwa pemberian dekamon sebagai zat pengatur tumbuh tidak berpengaruh terhadap produksi rumput bede, namun frekuensi penyemprotan pupuk daun $2 \mathrm{kali} /$ minggu berpengaruh sangat nyata terhadap jumlah tunas rumput bede pada dosis dekamon o $\mathrm{ml}$ dan o,6 ml. Dosis dekamon yang tepat bagi produksi rumput bede adalah tanpa dekamon dengan frekuensi penyemprotan 2 kali/minggu.
\end{abstract}

Kata kunci: Brachiaria decumbens, produksi, dekamon, pupuk daun

\section{ABSTRACT \\ RESPONSE OF BEDE GRASS (Brachiaria decumbens) PRODUCTION DUE TO DEKAMON HORMONE TREATMENT IN VARIOUS SPRAYING FREQUENCY OF GANDASIL D}

This study aims to determine the dosage of dekamon as the appropriate growth regulators at various frequencies spraying foliar fertilizer for grass Brachiaria decumbens production. The study was conducted for 4.5 months housed in the Central Animal Breeding and Forage Animal Feed (BPT-HMT) Department of Animal Husbandry and Animal Health in West Papua Province at Sumber Boga villages Masni District of Manokwari regency, while the analysis of dry matter in the Laboratory of Animal Nutrition and Feed, Faculty of Animal Husbandry the State of Papua University Manokwari. The method used is the method of experimental design completely randomized design (CRD) with two treatments. Treatment dekamon (D) with 6 levels is Do (without administration), D1 $=0.4 \mathrm{ml} / 250 \mathrm{ml}$ of water, $\mathrm{D} 2=0.5 \mathrm{ml} / 250 \mathrm{ml}$ of water, $\mathrm{D}_{3}=0.6 \mathrm{ml} / 250 \mathrm{ml}$ of water, $\mathrm{D}_{4}=0.7 \mathrm{ml} / 250 \mathrm{ml}$ of water and $\mathrm{D}_{5}=0.8 \mathrm{ml} / 250 \mathrm{ml}$ of water. Each stage treatment was repeated 5 times so that there are 30 units of the experiment. Furthermore, using 3 experimental plots with a size of $2.4 \times 2 \mathrm{~m}^{2} /$ plot for the treatment of foliar fertilizer spraying frequency with Gandasil D, each plot I (So) for no spraying, plot II (S1) for spraying 1 times/week and plot III (S2) for spraying 2 times/week. Data were statistically analyzed and the difference between the levels of a certain treatment were analyzed by t-test. Results of this study showed that administration of dekamon as growth regulators did not affect the growing of Bede grass, but the frequency of spraying foliar fertilizer 2 times/ week very significant effect on the number of tiller in a dosage dekamon o $\mathrm{ml}$ and $0.6 \mathrm{ml}$. Dekamon proper dosage for growing of Bede grass is without dekamon with spraying frequency of 2 times/week.

Keywords: Brachiaria decumbens, production, dekamon, D gandasil fertilizer 


\section{PENDAHULUAN}

Peningkatan populasi ternak ruminansia di Papua Barat harusnya juga dibarengi dengan ketersediaan hijauan pakan yang cukup memadai, baik segi kualitas atau mutu,kuantitas atau jumlah dan kontinyuitas atau ketersediaan sepanjang waktu. Kawasan ini merupakan wilayah yang potensial sebagai salah satu sentra produksi sapi potong ke depannya guna mengaktualisasikan gaung program pemerintah pusat dalam upaya pencapaian program swasembada daging nasional guna pemenuhan kebutuhan protein masyarakat. Hal ini ditunjang dengan ketersediaan lahan sebesar 75.0oo hektar yang didesain dengan pembangunan sejumlah ranch dengan model penggembalaan dimana jumlah populasi sapi potong mencapai 41.464 ekor, dimana jumlah ini terus meningkat dari tahun ke tahun (Suprihadi, 2011). Beberapa kendala yang dihadapi antara lain, rendahnya kualitas hijauan yang berimbas pada rendahnya kapasitas tampung pada beberapa padang penggembalaan yang ada, dimana spesies yang mendosminasinya adalah alang-alang (Imperata cylindrica). Upaya memperbaiki komposisi spesies merupakan solusi alternatifnya dengan mengintroduksi spesies hijauan pakan potensial.

Rumput Brachiaria decumbens (Bede) merupakan salah satu jenis rumput gembala yang potensial untuk dikembangkan dan dikelola dengan baik sebagai penyedia hijauan pakan dan menjadi alternatif bagi peternak dalam usaha peternakan yang dilakukan. Rumput ini memiliki keunggulan antara lain, sebagai rumput yang tahan kondisi kering atau mampu bertahan hidup dalam kondisi yang ekstrim seperti kekeringan atau kemarau, memiliki perakaran yang kuat dan cepat menutup tanah sehingga dapat mengurangi erosi tanah (Hidayat et al., 1997; AAK, 1983). Rumput ini juga memiliki palatabilitas yang baik bagi ternak ruminansia (Mannetje dan Jones, 1992) dan merupakan rumput padangan yang baik dan bila direnggut ternak akan membentuk kumpulan daun yang lebih terbuka (Reksohadiprodjo, 1981).

Dinas Peternakan dan Kesehatan Hewan Provinsi Papua Barat sudah mengembangkan rumput ini melalui Balai Pembibitan Ternak-Hijauan Makanan Ternak, yang bibitnya diperoleh dari padang penggembalaan Mangatas di Padang Sumatera Barat, sejak tahun 2013. Dalam pembudidayaannya, rumput ini belum dapat berproduksi dengan baik sebagaimana di daerah asalnya, sehingga diperlukan upaya khusus yang salah satunya dengan merangsang pertumbuhan akar dengan zat pengatur tumbuh dekamon dan produksi daun rumput dengan pemberian pupuk daun gandasil. Hormon pertumbuhan merupakan suatu pertahanan diri spesies terhadap pengaruh yang diterima sehingga bisa terus dapat mempertahankan kelangsungan hidupnya. Sedangkan pemberian pupuk daun dimaksudkan untuk meningkatkan produksi daun dan nilai gizi rumput bede. Dengan demikian studi ini bertujuan untuk mengetahui seberapa besar dosis zat pengatur tumbuh dekamon yang tepat dan frekuensi penyemprotan pupuk daun gandasil yang efektif bagi pertumbuhan rumput bede.

\section{MATERI DAN METODE}

Penelitian ini dilakukan selama 4,5 bulan dan berlokasi di Balai Pembibitan Ternak dan Hijauan Makanan Ternak (BPT-HMT) Dinas PKH Propinsi Papua Barat, SP 5 Kampung Sumber Boga Distrik Masni Kabupaten Manokwari selama dua tahap. Percobaan tahap satu bertujuan untuk mengetahui pengaruh pemberian dosis hormon terhadap produksi rumput Bede, sedangkan percobaan tahap dua untuk mengetahui pengaruh frekuensi penyemprotan hormon terhadap produksi rumput Bede. Percobaan tahap satu menggunakan rancangan acak lengkap (RAL), dengan 6 perlakuan dosis dan 5 ulangan. Perlakuan dosis dekamon yang digunakan adalah: Do (tanpa dekamon/kontrol), D1 (o,4 ml dekamon/250 $\mathrm{ml}$ air), D2 (o,5 ml dekamon/250 ml air), D3 (o,6 $\mathrm{ml}$ dekamon/250 $\mathrm{ml}$ air), D4 (o,7 ml dekamon/250 $\mathrm{ml}$ air), D5 (o,8 ml dekamon/250 ml air). Sedangkan untuk melihat efektivitas frekuensi penyemprotan dilakukan dengan membuat 3 petak percobaan yang berukuran 2,4 $\times 2 \mathrm{~m}$. Petak I, seluruh tanaman tidak disemprot dengan pupuk daun gandasil (So/kontrol). Petak II, seluruh tanaman disemprot dengan pupuk daun gandasil dengan frekuensi $1 \mathrm{kali} /$ minggu (S1). Sedangkan Petak III, seluruh tanaman disemprot dengan pupuk daun gandasil dengan frekuensi 2 kali/minggu. Pengacakan dan penempatan perlakuan dilakukan di dalam setiap petak. Semua data pengamatan dianalisis secara statistik dengan analisis ragam (Anova) dan perlakuan yang berpengaruh dilanjutkan dengan uji t.

Prosedur Pelaksanaan. Meliputi: (1) Penyiapan lahan/media tanam. Lahan yang disiapkan dengan ukuran $7 \times 2,4 \mathrm{~m}^{2}$ yang dibagi menjadi 3 petak dimana setiap petak berukuran $2,4 \times 2 \mathrm{~m}^{2}$, sedangkan jarak antar petak adalah $0,5 \mathrm{~m}$. Masing-masing petak dipasang plastik border sebagai pembatas antar perlakuan untuk frekuensi penyemprotan pupuk Gandasil daun. (2) Pembersihan lahan dan persiapan polibag. Pembersihan lahan dilakukan dengan membersihkan lahan dari pohon-pohon kecil dan semak belukar dengan menggunakan parang dan mesin babat rumput. Polibag diberikan label sesuai dengan perlakuan, kemudian tanah yang akan diisi terlebih dahulu dicampur merata dengan pupuk 
bokashi, dengan perbandingan $1 \mathrm{~kg}$ tanah : 62,5 g bokashi. Selanjutnya dimasukkan ke dalam polibag yang ada, setelah itu ditempatkan sesuai dengan denah percobaan dengan jarak antaranya $40 \mathrm{~cm}$. (3) Pemilihan bibit. Bibit yang digunakan berasal dari pols rumput bede dengan ukuran sekitar $20 \mathrm{~cm}$ dan ditanam 2 pols/polibag. (4) Penanaman. Pols yang sudah disiapkan, direndam ke dalam larutan dekamon, sesuai dengan perlakuan dosis dekamon. setiap dosis ditempatkan secara terpisah pada 6 botol aqua $650 \mathrm{ml}$ selama 1 menit. Setelah itu ditanam pada setiap polibag yang ada sesuai kode perlakuan. (5) Pemeliharaan. Pemeliharaan dilakukan dengan penyiraman tanaman dan penyiangan. Penyiraman dilakukan dua kali sehari yaitu pada waktu pagi hari dan waktu sore hari, kecuali pada saat hujan. Sedangkan penyiangan dilakukan setiap 2 minggu sekali hingga tanaman berumur 7 minggu. (6) Pemupukan. Pemupukan dilakukan pada pagi hari pukul 07.00-10.00 WIT atau pada sore hari pukul 15.00-18.0o WIT dengan melakukan penyemprotan pupuk daun gandasil setelah daun tumbuh sempurna yaitu pada umur 4 minggu sesuai dengan taraf perlakuan. (7) Defoliasi. Defoliasi dilakukan saat tanaman bede berumur 7 MST (minggu setelah tanam) dengan cara memotong rumput bede rata dengan permukaan tanah pada polibag.

\section{HASIL DAN PEMBAHASAN}

\section{Produksi Berat Segar}

Rata-rata produksi berat segar (PBS) rumput Brachiaria decumbens menurut perlakuan zat pengatur tumbuh dekamon dan pada berbagai frekuensi penyemprotan pupuk daun gandasil disajikan pada Gambar 1.

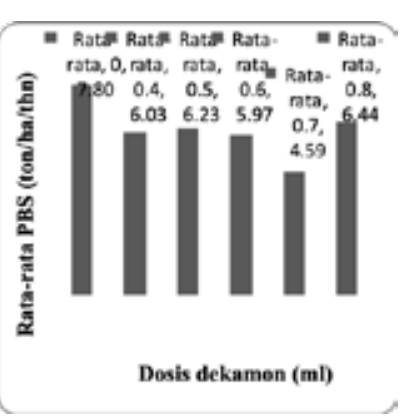

(a)

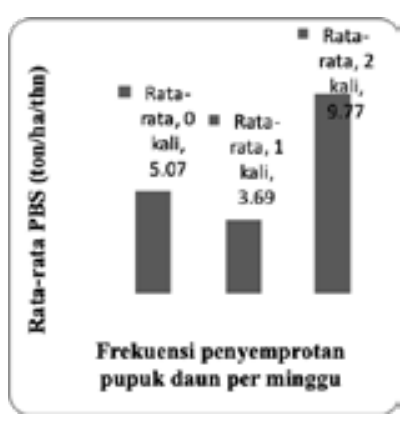

(b)
Gambar 1. Rata-rata produksi segar rumput Brachiaria decumbens (a) dengan perlakuan dosis dekamon (b) pada berbagai frekuensi penyemprotan pupuk daun

Hasil analisis ragam menunjukkan bahwa perlakuan pemberian zat pengatur tumbuh tidak berpengaruh nyata $(\mathrm{P}>0.05)$ terhadap produksi berat segar rumput Brachiaria decumbens. Hasil uji t menunjukkan bahwa terdapat perbedaan yang nyata terhadap produksi berat segar pada frekuensi penyemprotan pupuk daun tanpa perlakuan dosis dekamon dan dengan perlakuan dosis dekamon o.6 $\mathrm{ml} / 250 \mathrm{ml}$ air pada frekuensi penyemprotan pupuk daun o kali vs 2 kali per minggu dan 1 kali vs 2 kali per minggu. Kapasitas produksi bahan segar rumput bede mencapai 90-150 ton/ha/tahun (Soetanto dan Subagyo,1988), namun pada penelitian ini hanya mencapai 6,17 ton/ha/tahun. Hal ini diduga karena rumput ini dipanen pada umur yang muda dan belum mencapai masa optimum di fase vegetatif, sehingga produksinya masih belum optimal. Jumin (2008) menyatakan bahwa peningkatan produksi berbanding lurus dengan pertumbuhan relatif suatu tanaman.

\section{Rasio Daun Batang}

Rasio daun batang dapat dijadikan parameter kualitas hijauan pakan karena rasio daun batang menunjukkan perbandingan antara jumlah daun dan batang yang dihasilkan, dimana kualitas daun umumnya lebih baik daripada batang. Semakin tinggi rasio daun dan batang kecenderungan kualitas hijauan pakan semakin baik. Rata-rata pengamatan rasio daun batang rumput bede berdasarkan dosis dekamon pada frekuensi penyemprotan pupuk daun gandasil selama pengamatan disajikan pada Gambar 2.

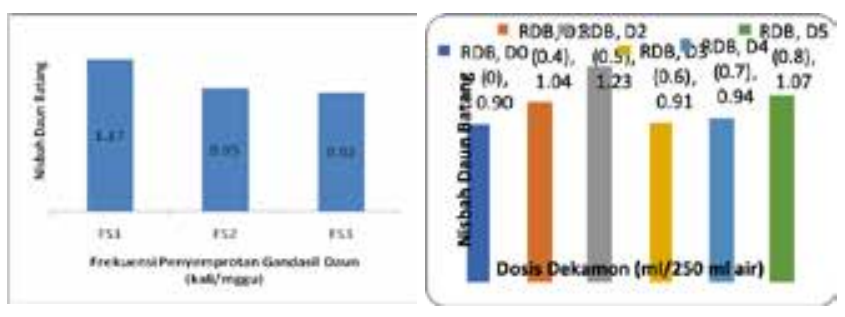

Gambar 2. Rata-rata rasio daun batang rumput bede

Rasio daun batang penting karena daun merupakan organ metabolisme dan kualitas batang sebagain besar dipengaruhi oleh strukturnya (Shehu et al. 2001). Menurut Humpreys (1991) dan Whiteman (1980), imbangan daun batang dipengaruhi oleh faktor jenis tanaman, pemupukan dan umur tanaman. Dimana rumput tropis lebih bersifat membentuk batang secara kontinyu dan cenderung berbunga terus. Dalam hal pemupukan, dengan meningkatnya dosis $\mathrm{N}$ dapat meningkatkan proporsi daun tetapi juga ada yang mengalami penurunan. Sedangkan untuk umur, semakin tua tanaman maka cenderung untuk membentuk batang dalam proses akan berbunga. Selain itu berpengaruh terhadap kandungan nilai gizi hijauan.

Peningkatan interval defoliasi dapat menurunkan 
rasio daun dan batang yang dihasilkan. Hal ini sesuai dengan Widayanti (2008), perlakuan umur pemotongan Borreria alata 45 hari $(2,25 \mathrm{~g} /$ polibag $)$ dan 55 hari (2,15 g/polibag) menghasilkan rasio daun dan batang lebih tinggi daripada umur pemotongan 65 hari (1,12 g/polibag). Begitu pula dengan perlakuan pemupukan dimana pemupukan N:P:K (1:1:1) menghasilkan rasio daun dan batang lebih tinggi (3,08 g/polibag) dibandingkan perlakuan lainnya $\mathrm{N}: \mathrm{P}: \mathrm{K}(1: 1: 2), \mathrm{N}: \mathrm{P}: \mathrm{K}$ (1:2:1) dan N:P:K (2:1:1) dimana masing-masing 1,76, 1,58 dan 1,31 gram per polibag. Hasil penelitian Vanis (2007) memperlihatkan bahwa interval pemotongan 50 hari pada rumput gajah (Pennisetum purpureum) menghasilkan rasio daun dan batang lebih tinggi daripada interval pemotongan 60 hari.

\section{Produksi Bahan Kering}

Rata-rata produksi bahan kering (PBK) rumput Brachiaria decumbens berdasarkan perlakuan zat pengatur tumbuh dekamon dan pada berbagai frekuensi penyemprotan pupuk daun gandasil disajikan pada Gambar 3 .

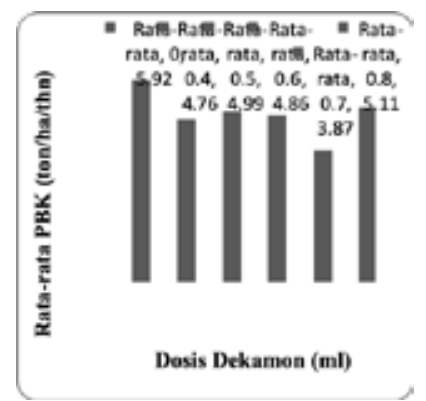

(a)

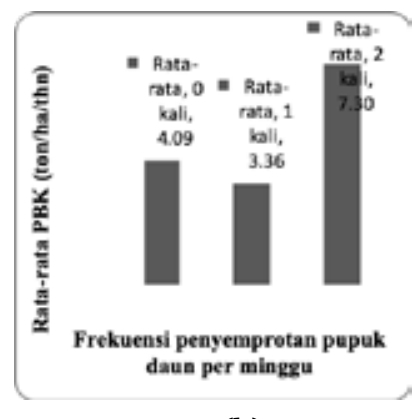

(b)
Gambar 3. Rata-rata produksi bahan kering rumput Brachiaria decumbens (a) dengan perlakuan dosis dekamon (b) pada berbagai frekuensi penyemprotan pupuk daun gandasil

Hasil analisis ragam menunjukkan bahwa perlakuan pemberian zat pengatur tumbuh memberikan pengaruh tidak nyata $(\mathrm{P}>0.05)$ terhadap produksi bahan kering rumput Brachiaria decumbens. Uji statistik menunjukkan bahwa terdapat perbedaan yang nyata terhadap produksi bahan kering rumput bede pada frekuensi penyemprotan pupuk daun tanpa perlakuan dosis dekamon dan dengan perlakuan dosis dekamon $0,6 \mathrm{ml} / 250 \mathrm{ml}$ air pada frekuensi penyemprotan pupuk daun o kali vs 2 kali per minggu dan 1 kali vs 2 kali per minggu.

Rendahnya produksi bahan kering yang dicapai dalam penelitian ini yaitu 7,30 ton/ha/tahun jika dibandingkan dengan Hidayat et al. (1997), dimana produksi bahan keringnya dapat mencapai 36,1 ton/ ha/tahun pada interval defoliasi 40 hari. Hal ini terjadi akibat umur defoliasi yang terlalu cepat karena rumput bede masih dalam fase pertumbuhan vegetatif sehingga produksi produksinya yang sejalan dengan produksi bahan segar yang dihasilkan.

Tanaman yang masih muda mempunyai kandungan bahan kering yang relatif rendah, karena secara fisiologis masih banyak mengandung sel aktif, dimana sel-sel tersebut banyak mengandung air (Soetanto dan Soebagyo 1988). Selain itu fungsi pupuk gandasil daun lebih tepat digunakan pada fase vegetatif yaitu saat tanaman masih dalam masa pertumbuhan (Yazid, 2013). Hal ini sejalan dengan Subagio dan Kusmartono (1988) yang menyatakan bahwa produksi bahan kering akan bertambah dengan bertambahnya umur pemotongan, dimana peningkatan produksi bahan kering ini terjadi karena meningkatnya produksi segar tanaman. Pada tanaman yang tua hasil aktivitas fotosintesis selain digunakan untuk pertumbuhan juga disimpan sebagai cadangan makanan sehingga kandungan dan produksi bahan kering bertambah dengan meningkatnya umur pemotongan. Hal ini sesuai dengan McIlroy (1976) bahwa semakin pendek umur defoliasi suatu tanaman maka semakin sedikit kesempatan daun pada tanaman memanfaatkan sinar matahari untuk pembentukan bahan kering tanaman. Selanjutnya umur defoliasi yang terlalu pendek mengakibatkan hasil fotosintesis terbatas dan sebaliknya interval defoliasi yang terlalu lama akan memproduksi bahan kering tinggi.

Perlakuan pemberian zat pengatur tumbuh dekamon tidak memberikan pengaruh nyata $(\mathrm{P}>0,05)$ terhadap produksi rumput bede. Hal ini terjadi akibat kurang lamanya waktu yang digunakan untuk perendaman pols rumput bede sehingga menyebabkan respon penyerapan hormon ke dalam pols menjadi tidak sempurna karena protein penerima di dalam pols rumput bede tersebut tidak dapat menerimanya akibat serapan atau absorbsi zat-zat yang belum optimal.

Salisburry dan Rosss (1995) menyatakan bahwa perbedaan kepekaan jauh lebih penting dalam menentukan efek suatu hormon daripada konsentrasi hormon tersebut Agar hormon tumbuhan yang terdapat dalam jumlah mikromolar atau submikromolar itu bersifat aktif dan khas, harus ada tiga bagian utama pada sistem respons, yaitu: 1) hormon harus ada dalam jumlah yang cukup di dalam sel yang tepat. Hormon harus dikenali dan diikat oleh setiap kelompok sel tanggap terhadap hormon; 2) molekul protein memiliki struktur yang kompleks yang diperlukan untuk mengenali dan memilih diantara sejumlah molekul yang jauh lebih kecil (protein penerima); dan 3) protein penerima tersebut harus menyebabkan perubahan metabolik lain yang mengarah pada penguatan isyarat atau 
kurir hormon. Penguatan terjadi secara berurutan, sebelum respons terhadap hormon akhirnya terjadi. Selain itu, juga terjadi perubahan kemampuan dalam memperkuat isyarat hormone. Bagian lain tumbuhan atau bagian dari spesies lain mungkin memberikan respons dengan cara yang berbeda.

\section{SIMPULAN}

Pemberian zat pengatur tumbuh dekamon tidak memberikan pengaruh terhadap produksi rumput bede, namun frekuensi penyemprotan pupuk daun gandasil 2 kali seminggu berpengaruh nyata pada dosis dekamon kontrol dan $0,6 \mathrm{ml} / 250 \mathrm{ml}$ air. Selain itu, frekuensi penyemprotan pupuk daun gandasil yang tepat adalah dua kali per minggu.

\section{UCAPAN TERIMA KASIH}

Disampaikan kepada Dinas Peternakan dan Kesehatan Hewan Provinsi Papua Barat yang telah bekerja sama dalam pelaksanaan penelitian di lapangan.

\section{DAFTAR PUSTAKA}

Aksi Agraris Kanisius.1983. Hijauan Makanan Ternak Potong,Kerja dan Perah. Yayasan Kanisius. Yogyakarta.

BPS. 2013. Populasi Ternak Besar Menurut Kabupaten/ Kota dan Jenisnya Tahun 2010-2012 (ekor). Badan Pusat Statistik Papua Barat. Sumber: irjabar. bps.go.id)? no=910\&pilih=tabel1]. Diakses tanggal 4 Juni 2014.

Humpreys L. R. 1991. Tropical Pasture Utilisation. Melbourne Sidney: Cambridge University Press.
Mannetje, L.'t. dan R. M, Jones. 1992. Plant resources of south East asia No 4. Forages Prosea Bogor, Indonesia.

Reksohadiprodjo, S. 1981. Produksi Tanaman Hijauan Makanan Ternak Tropik. Fakutas ekonomi Universitas Gajah Mada. Yogyakarta.

Salisburry and Ross. 1995. FisiologiTumbuhan. Jilid 3. Penerbit: Institut Teknologi Bandung. Bandung.

Soetanto H, dan I. Subagyo, 1988. Landasan Agrostologi. Nuffic-Universitas Brawijaya Malang.

Subagyo I, dan Kusmartono,1988. Ilmu Kultur Padangan. Malang: Nuffic, Fakultas Peternakan Universitas Brawijaya.

Suprihadi, M. 2011. Papua Barat Jadi Sentra Produski Sapi. Harian Kompas. [Regional Kompas.com/ $\mathrm{read} / 2011 / 08 / 10 / 10564665 /$ Papua.Barat.Jadi. Sentra.Ternak.Sapi]. Diakses tanggal 2 Juni 2014.

Shehu Y., Alhassan WS, Paul UR, Philips CJC. 2001. Yield and Chemical composition responses of Lablab purpureus to nitrogen, phosporus and potassium fertilizer. J. Tropical Grasslands 35: 180-185.

Vanis R. D. 2007. Pengaruh pemupukan dan interval defoliasi terhadap pertumbuhan dan produktivitas rumput gajah (Pennisetum purpureum) di bawah tegakan pohon sengon (Paraserianthes falcataria). [Skripsi]. Bogor: Fakultas Peternakan IPB.

Whiteman P.C. 1980. Tropical Pasture Science. Australia: Oxford University Press.

Widayanti A. 2008. Efek pemotongan dan pemupukan terhadap produksi dan kualitas Borreria alata sebagai hijauan makanan ternak berkualitas tinggi. Skripsi. Bogor: Fakultas Peternakan IPB. 